easily remembered. The dreams of epileptics are simple, those of hysterics complex and dramatic, and often 'macrozooscopic.' One of the most interesting points connected with the dreams of hysterics is their influence on their waking life and course of the symptoms. Dr. de Sanctis found this influence; but only in 6 of his cases did it seriously aggravate the disease. In more than half the cases the dreams of the previous night influenced the humor and conduct of the following day.

W. J.

\title{
SUBLIMINAL CONSCIOUSNESS, ETC.
}

Subliminal Self, or Unconscious Cerebration? Arthur H. Pinrce.

Proceedings of Soc. for Psych. Research. Vol. XI., pp. 317325. (1895.)

Reply to the same. Frank Podmore. Ibid., pp. 325-332.

Ueber Spaltung der Persönlichkeit (Sogenanntes Doppel-ich.)

Dr. Freihgrr von Schrink-Notzing. Wien, Holder, 1896.

$8^{\circ}$. Pp. 23 .

Die Mehrheit geistiger Persönlichkeiten in einem Individuum.

Eine Psychologische Studie. Dr. S. Landmann. Stuttgart,

Enke, 1894. 8०. Pp. 186.

The well-known observations made on hypnotic and hysteric subjects and automatic writers by Gurney, Janet, Binet and others, and which by their authors are supposed to prove that mutually disconnected currents of conscious life can simultaneously coexist in the same person, are subjected to critical reinterpretation by Messrs. Landmann, von Schrenck and Pierce. All these writers deal with theory, no one of their essays bringing out any new kinds of facts.

Mr. Pierce thinks that the performances, such as the executing of orders, answering of questions in writing, etc., that may go on whilst the subject's upper consciousness ignores what happens and is otherwise occupied, are all due to unconscious cerebration. Educated to certain aptitudes, the brain is now able to perform them whilst its consciousness is altogether engrossed with other conduct simultaneously going on. The notion of multiple consciousness has no limit if we begin to use it. There is no direct proof of the supposed split-off consciousness, for by the hypothesis, if split off it is never known to the 'person,' and if remembered later it was probably not split-off.

Mr. Podmore objects that Mr. Pierce talks as if consciousness and brain-processes formed an alternative. He himself favors the parallelistic theory and considers some consciousness to accompany all pro- 
cesses, its degree fluctuating; he disbelieves in two disconnected systems of consciousness forming a definitely dual control, and thinks the facts best covered by the conception of a conscious field with a single bright center and a margin stretching indefinitely away into twilight.

Baron von Schrenck holds somewhat similar views. He believes that only those processes that form the 'crest of the wave' of cerebral excitement give rise to full consciousness. But the wave-crest is always shifting its place; and a system of cerebral operations, A, started with full consciousness, can run on for a certain time, even although the wave-crest may forthwith have proceeded elsewhere and started another system, B, which latter then in its turn may run on sub-consciously, whilst the wave-crest reverts to the now subsiding system $A$, and with a stroke of full consciousness starts it up to activity again. We have only to suppose, now, that the pulses of conscious attention that accompany the A-process and the B-process severally, as the wave crest oscillates to and fro, fail to combine into a united memory system, and we have, according to von Schrenck, all the phenomena of simultaneous double self, so-called, or split consciousness, explained on the type of alternation of systems of ideas with the memorybridge between them gone. The theory of simultaneous coexistence of fully conscious systems thus falls to the ground.

Dr. Landmann accounts for the facts by assuming three levels of brain-operation, only one of which has self-consciousness attached to it. This latter is the consciousness of psychic activity as such. It is attached exclusively to certain (undesignated) processes in the cortex, and only he who has it can say 'I.' The second level is that of ideation and association without this self-consciousness (unselbstbewusste Vorstellungen); whilst the third level belongs to the 'subcortical centers' and is often spoken of as 'unconscious' by Dr. L., though he also repeatedly speaks of the Vorstellungen and Gefühle that go with the subcortical centers. Whole groups of cortical cells can fall into isolated activity; the subcortical cells can act by themselves, and the cells of self-consciousness can either coöperate or not coöperate with the rest. But the self-consciousness is either wholly where it is, or else not there at all; so that the ordinary talk about fractioning of the personality, upper and lower selves, etc., is absurd, 'personality' and 'self' being indivisible elements of the mental life. The only possible doubling of the self is where it acts in alternation, first with one and then with another system of ideas.

Where one self appears to be writing automatically whilst another 
self converses at the same time through the mouth, the latter self is the sole real self engaged; the automatic performances being the work 'of the 'non-self-conscious' parts of the cortex, and of the 'unconscious' basal ganglia. Dr. L. applies these principles in an intolerably rambling style and with tedious minuteness to the elucidation of Janet's and Binet's observations, thinking (strange to say) that their merely descriptive phrases about ' dissociation of the personality,' etc., consitute a 'theory' irreconcilable with his own.

The really urgent problem in these phenomena of split or uncoupled mental life is that of the conditions of splitting and coupling-again, be they cerebral conditions or physical conditions, or both. What happens when any one system of ideas or of brain activities get so thoroughly shunted off and ignored by the consciousness that goes with the rest? On this problem no one of our three authors can be said to throw any more positive light than Mr. Myers or Janet. Myers would be the first to say that his phrase 'subliminal self' is only a temporary noun of designation for a certain group of facts. Janet would say the same of his phrase 'defective power of conscious synthesis.' But their three critics, each with his own notion of a unique activity of self-consciousness which cannot be split, seem to me to carry matters backwards rather than forwards, and to tend, if anywhere, towards a somewhat pre-Lockian and non-empirical point of view.

W. J.

Introduction to Philosophy. F. PAuLsen. Translated by F. ThiLly. With an Introduction by W. JAMEs. New York, Henry Holt \& Co., I 895. Pp. xix +437 .

Professor Paulsen's Introduction has been in the hands of the students of philosophy in the original long enough to have become familiar. To those who have not known the original, Professor James' preface will be sufficient recommendation. The features of the book which strike the present reviewer may be briefly indicated. First, the readable character of the author's expositions is noteworthy. Then the comprehensiveness of the book is surely a great recommendation of it for class-room work.

As to doctrine, several things are striking. Professor Paulsen's 'voluntaristic' psychology gives character to his philosophical views all the way through (see pp. $3^{1} 3,3^{20} \mathrm{f}$.), and it is this standpoint, possibly, that leads him to subordinate the problem of epistemology, as he does, to that of philosophy in general (pp. 349, 353). But the tendency 